\title{
Effects of using mandatory technical exercises on the performance level of some individual and combined skills of junior soccer players
}

"Dr/ Ahmed Mohamed Ibrahim Al-henedy

\section{Introduction and Research} Problem:

There is no doubt that football has received great attention from researchers and scholars who have addressed many of their problems due to the nature of the changing technical performance in football, and thus shows the important role of planning for training, which is linked to a continuum and integrated stages and aspects based on scientific grounds include Preparation of training programs as well as development of appropriate training methods for different age stages, which contribute to the preparation of the player properly prepare him to carry out his defensive and offensive duties more effectively and positively during the game.

Nick Harris (2013) 11 points out that modern planning in football training plays a key role in achieving high levels of sport, whether physical, skill, tactical, or psychological. Training theories and modern methods have become an important input in the light of the player's abilities and abilities. .

Performance in the sport of football at the local and international levels currently requires the availability of many effective and distinctive characteristics of the individual and collective performance of the players. They are sports activities with many different situations.

Nody Shadin (2016) (12) points out that the kinetic performance of the kinetic system and the importance of looking at it as a whole unit and not just the group of constituent parts, where the parts are interconnected through several links and mutual gain new properties were not included in the characteristics of the.

Ahmed Haider (2012)

(3) emphasizes that the training

"Instructor at the Department of Collective Games and Racquet Sports, Faculty of Physical Education, Tanta University 
of the youth on a variety of motor performance similar to the requirements of the game allows him to choose the best according to the actual playing positions and increase his ability to maneuver and implement the plans in different places and directions and not surprised by positions not trained, And thus achieve the speed of accurate performance and accuracy in the implementation of the duty of skill and plan.

There are planning considerations that the player must take into account in the performance of skills, including the adjustment in the basic configuration of the skill so that a part of the preparatory period is reduced, shortening the time of the stage so that it is difficult for the competitor to determine its reaction time in time for not predicting the behavior of the motor, Performance, so achieving a high level of skill performance requires the coach to take care to prepare all systems for the preparation of the player in changing circumstances and deal with it flexibly while maintaining the basics of skill, so it is important to use training forms that are close to The form of competition in football is to be acquired as early as possible so that time can be used in training on these motor performances. (3: 8)

There have been several studies that dealt with the effect of the technical aspects of football players on the level of performance in general, pointing out that in order to achieve the results of advanced must begin to prepare them from the beginning of the youth, and was guided by the facts and the scientific basis for the planning process to build training programs Which lead to the development of the training situation for young people and make it technically fit (9)

a study that showed that more than $90 \%$ of the trainers use non-objective methods during the training, which leads to many errors, and Talal Abdul-Jawad's study (2011) (6), which reached the positive impact Of the performance of the offensive in the African Nations Cup in Ghana in 2008 on the performance level of the offensive (individual, composite and group) of the research sample, and the study 
of Ahmed Ibrahim (2011) (2) in which he achieved the similarities of compositecombined performance of the different play centers in Egypt and the international teams At the World Youth Championship 2009, the study of Mustafa (2015) (10), which found that physical and skill level has improved for the experimental group in the scrolling and correction accuracy and running the ball

Compulsory technical training is one of the basic skills training methods. It shows the player's accuracy in basic skill performance, helps to develop the skill of the players, and increases their ability to act in all different play situations in terms of dealing with the ball whether individually (one skill), Or as an integrated image (overlapping more than one skill with each other)

researcher shows the importance of the technical preparation of the player in terms of developing and mastering the individual and integrated skills through a training program containing one of the methods of training on the basic skills of "compulsory technical exercises" and their impact on the implementation of the planning side efficiently and effectively and thus resolving the match results for the team High level of mastery of basic skills without falling in performance level.

\section{-Research goals:}

The aim of this research is to design a training program for compulsory technical training 1- The impact of the proposed program on the performance of some of the skills of individual footballers.

2-The impact of the proposed program on the level of performance of some of the skills integrated with footballers.

\section{Research hypotheses:}

* The proposed training program has a positive impact on the level of performance of individual skills for the benefit of the experimental group.

* The proposed training program will have a positive impact on the level of performance of some integrated skills for the benefit of the experimental group.

- There are statistically significant differences between the two dimensions of the 
experimental and control groups in the skill performance variables and for the postmeasurement of the experimental group.

- There is a difference in the improvement ratio between the experimental and control groups in the individual and integrated skills for the benefit of the experimental group.

\section{Search procedures}

\section{Research Methodology:}

The researcher used the experimental method using the post-pre experimental design for two groups, one experimental and the other control.

\section{Research community:}

The research community of the 15-year-old youth footballers in Gharbia Governorate is a participant of the Western Football Association for the 2017/2018 sports season (7) clubs.

\section{The research sample:}

The research sample included 15 years of football in the Tanta Sports Club of the Egyptian Football Federation branch in Al Gharbia for the 2017/2018 sports season. It was chosen deliberately to cooperate with the officials of the club and to provide conditions for applying the research procedures. The number of participants was 42 , (30) arising from the same research community and from outside the basic sample from the municipality club of Mahalla, and the table Figure (1) shows the description of the research sample:

Table (1)

Characterization of the research sample

\begin{tabular}{c|c|c|c|c|c}
\hline \hline $\begin{array}{c}\text { Type of } \\
\text { sample }\end{array}$ & Pilot & Experimental & Control & Excluded & Total \\
\hline \hline Players no. & 10 & 15 & 15 & 2 & 42 \\
\hline Percentage \% & $23.80 \%$ & $35.75 \%$ & $35.75 \%$ & $4.70 \%$ & $100 \%$ \\
\hline \hline
\end{tabular}

\section{Equal search groups:}

The parity between the experimental and control groups was determined by the variables (growth - physical level of individual skills combined) under consideration, and Table (2) shows this. 
Table (2)

The equivalence of the two groups of research in variables (growth physical) and the level of skills (single - integrated) $n=1 n=15$

\begin{tabular}{|c|c|c|c|c|c|c|c|c|}
\hline & & & & Experin & ental group & Cont & ol group & \\
\hline & Variables & skills & unit & SMA & $\begin{array}{l}\text { standard } \\
\text { deviation }\end{array}$ & SMA & $\begin{array}{l}\text { standard } \\
\text { deviation }\end{array}$ & calculated \\
\hline & Age & & Year & 15,57 & 0,35 & 15,65 & 0,31 & $-0,65$ \\
\hline 5 & Body hei & & $\mathrm{Cm}$ & 167,36 & 4,48 & 165,83 & 5,12 & 0,87 \\
\hline نํ. & body wei & & $\mathrm{Kg}$ & 66,56 & 3,86 & 65,60 & 3,34 & 0,73 \\
\hline & Training & & Year & 3,36 & 1,11 & 3,75 & 1,17 & $-0,91$ \\
\hline & Transitio & speed & $\mathrm{S}$ & 6,02 & 0,33 & 6,13 & 0,42 & 0,84 \\
\hline ? & Muscle c & pacity & $\mathrm{Kg}$ & 29,06 & 2,81 & 28,36 & 2,72 & 0,69 \\
\hline$\widehat{\imath}$ & Flexibilit & & $\mathrm{Cm}$ & 9,16 & 0,65 & 9,40 & 0,71 & 0,93 \\
\hline & agility & & $\mathrm{Cm}$ & 10,83 & 0,32 & 10,72 & 0,39 & 0,89 \\
\hline & Control t & e ball & Degree & 52,67 & 6,79 & 54,67 & 7,18 & 0,78 \\
\hline$\pi$ & Various 1 & assing & Degree & 61,33 & 3,39 & 62,67 & 4,42 & 0,93 \\
\hline$\tilde{\sigma}$ & Accuracy & eam pitch & Degree & 62,00 & 7,48 & 63,33 & 6,99 & 0,50 \\
\hline ב & $\begin{array}{l}\text { The accuracy } \\
\text { ball directly } \mathrm{b}\end{array}$ & $\begin{array}{l}\text { of passing the } \\
\text { the head }\end{array}$ & Degree & 18,00 & 4,00 & 18,67 & 3,39 & 0,49 \\
\hline & $\begin{array}{l}\text { Shooting } \\
\text { a specific }\end{array}$ & $\begin{array}{l}\text { he ball to } \\
\text { part }\end{array}$ & Degree & 63,33 & 6,99 & 61,33 & 7,18 & 0,77 \\
\hline & Control & Chest & $S$ & 5,87 & 0,36 & 5,94 & 0,35 & 0,58 \\
\hline & then & Thigh & $\mathrm{S}$ & 5,67 & 0,36 & 5,76 & 0,41 & 0,60 \\
\hline & pass & Suppress & $\mathrm{S}$ & 5,42 & 0,31 & 5,51 & 0,28 & 0,81 \\
\hline & Control & Chest & $S$ & 6,02 & 0,37 & 6,13 & 0,41 & 0,76 \\
\hline & then & Thigh & $S$ & 5,84 & 0,73 & 5,97 & 0,80 & 0,86 \\
\hline & shooting & Suppress & S & 5,63 & 0,69 & 5,87 & 0,79 & 0,86 \\
\hline & $\begin{array}{l}\text { Control the } \\
\text { pass }\end{array}$ & dodge then & S & 9,83 & 0,73 & 9,99 & 0,93 & 0,53 \\
\hline है & Control & en dodge & $\mathrm{s}$ & 9,22 & 0,47 & 9,33 & 0,41 & 0,72 \\
\hline D્0 & and then & hooting & Degree & 24,00 & 8,00 & 26,77 & 9,43 & 0,84 \\
\hline & $\begin{array}{l}\text { Control } t \\
\text { ball then }\end{array}$ & $\begin{array}{l}\text { en run the } \\
\text { ass }\end{array}$ & $S$ & 9,53 & 0,59 & 9,64 & 0,68 & 0,48 \\
\hline & Control tl & en run the & $\mathrm{S}$ & 8,99 & 0,45 & 9,14 & 0,43 & 0,91 \\
\hline & ball and th & n shooting & Degree & 32,67 & 5,73 & 31,33 & 6,18 & 0,61 \\
\hline & $\begin{array}{l}\text { Control the } \\
\text { run and pas }\end{array}$ & dodge then & S & 11,07 & 0,47 & 10,97 & 0,44 & 0,65 \\
\hline & Control then & lodge then run & $S$ & 11,29 & 0,42 & 11,37 & 0,43 & 0,51 \\
\hline & & & Degree & 21,33 & 4,98 & 22,67 & 4,42 & 0,77 \\
\hline
\end{tabular}

The value of the table "T" at the level of $0.05=2,048$ 
Table (2) shows that there are no statistically significant differences at the level of 0.05 between the experimental and control groups in the variables (growth - physical) and skill level (single - merged) in the research, which indicates the equivalence of the two groups of research in those variables.

-Data collection tools and tools:

\section{-Expert opinion poll}

The researcher designed an expert survey form to determine:

-The most appropriate compulsory technical exercises for applying the research sample 15 years. Annex (2)

-The most appropriate tests that measure the "physical and technical" aspects of the junior research sample. Annex (3)

-Foundations and components of the proposed training program for the research sample. Annex (4)

-Proposed training program: Annex (6)

\section{-Program Objective:}

The proposed training program aims at identifying the effect of a compulsory technical training program on the performance of some individual and integrated skills among the football youth.

\section{-Program Characteristics:}

The researcher identified the characteristics of the proposed training program as follows:

-Program Periods: The preparation period has been set as one season period to implement the proposed training program.

-Number of weeks of program:

10 consecutive weeks.

-Weekly training units: The number of weekly training units was set at (4) training modules.

-Training times: The training times for the proposed training program during the preparation period were set at a total of (80) training hours (4800 minutes) distributed as follows: 1 -General preparation period: three weeks with a total number of hours (16) and a capacity of (960)

\section{2-Special Preparation Period:}

Three weeks with total number of hours (24) time (1440)

r-Preparation period for games: four weeks with a total number of hours (40) time (2400)

-Content of the program: The content of the proposed 
training program was determined by a set of technical exercises

Which is aimed at improving the individual and integrated skills (under study) with a total of (166) training distributed as follows:

-Individual training

training.

-Couple exercises

training.

-Exercises with three players and the number of (20) training.

-Training of four players (6) training.

\section{-Components of the training module in the proposed program:}

The daily training module consisted of four parts (warmup, physical preparation, skill preparation, and planning). The required technical training was included in the proposed training program during the skill preparation part according to the specific times of each preparation period. Annex.

-Application of the proposed program:
The proposed training program was applied for 10 (10) consecutive weeks during the period from $17 / 7 / 2017$ to $24 / 9 / 2017$ on the members of the experimental group.

-Search metrics:

-Pre

measurements: conducted during the period from $14 / 7 / 2017$ to $16 / 7 / 2017$ on the experimental and control research groups "basic research sample" in the stadiums of Tanta Sports Club, and the strength of each of the 15playres .

\section{-Dimension measurements:}

After the end of the period of application of the program, the dimension measurements were carried out during the period from $26 / 9 / 2017$ to $27 / 9 / 2017$ on the two research groups with the same conditions and the application of the application of pre measurements.

-View and discuss the results.

-Presentation and discussion of the results of the first hypothesis: 
Table (3)

The significance of the differences between the pre and post measurements of the experimental group In the level of individual skills under study $(n=15)$

\begin{tabular}{|c|c|c|c|c|c|c|c|}
\hline \multirow[b]{2}{*}{ Serial } & \multirow[b]{2}{*}{ Variables } & \multirow[b]{2}{*}{$\begin{array}{c}\text { Measure } \\
\text { unit }\end{array}$} & \multicolumn{2}{|c|}{ Pre measure } & \multicolumn{2}{|c|}{ Post measure } & \multirow{2}{*}{$\begin{array}{c}\text { T value } \\
\text { calculated }\end{array}$} \\
\hline & & & SMA & $\begin{array}{l}\text { standard } \\
\text { deviation }\end{array}$ & SMA & $\begin{array}{l}\text { standard } \\
\text { deviation }\end{array}$ & \\
\hline 1 & Control the ball & Degree & 52,67 & 6,79 & 72,00 & 7,48 & $* 6,25$ \\
\hline 2 & Various passing & Degree & 61,33 & 3,39 & 69,33 & 4,42 & $4,36 *$ \\
\hline 3 & $\begin{array}{l}\text { Accuracy Seam } \\
\text { pitch }\end{array}$ & Degree & 62,00 & 7,48 & 74,00 & 8,00 & $4,06 *$ \\
\hline 4 & $\begin{array}{l}\text { The accuracy of } \\
\text { passing the ball } \\
\text { directly by the } \\
\text { head }\end{array}$ & Degree & 18,00 & 4,00 & 24,83 & 2,49 & $6,46^{*}$ \\
\hline 5 & $\begin{array}{l}\text { Shooting the } \\
\text { ball to a } \\
\text { specific part }\end{array}$ & Degree & 63,33 & 6,99 & 82,00 & 9,09 & $6,67 *$ \\
\hline
\end{tabular}

*The value of the table "T" at a significant level of $0.05=2,145$

Table (4)

Significance of differences between the pre and post measurements of the control group IN the level of individual skills under study $(\mathbf{n}=15)$

\begin{tabular}{c|l|c|c|c|c|c|c}
\hline \hline \multirow{2}{*}{ Serial } & \multirow{2}{*}{ Variables } & \multirow{2}{*}{$\begin{array}{c}\text { Measure } \\
\text { unit }\end{array}$} & \multicolumn{2}{|c|}{ Pre measure } & \multicolumn{2}{|c|}{ Post measure } & \multirow{2}{*}{ T value } \\
\cline { 4 - 7 } & & & SMA & $\begin{array}{c}\text { standard } \\
\text { deviation }\end{array}$ & SMA & $\begin{array}{c}\text { standard } \\
\text { deviation }\end{array}$ & calculated \\
\hline \hline 1 & $\begin{array}{l}\text { The ball tilts } \\
\text { in time }\end{array}$ & $\mathrm{S}$ & 11,98 & 0,79 & 12,92 & 0,79 & 3,12 \\
\hline 2 & $\begin{array}{l}\text { Control the } \\
\text { ball }\end{array}$ & Degree & 54,67 & 7,18 & 62,00 & 8,33 & 3,25 \\
\hline 3 & Scrolling & Degree & 62,67 & 4,44 & 68,00 & 4,00 & 3,35 \\
\hline 4 & $\begin{array}{l}\text { The } \\
\text { accuracy of } \\
\text { the seam }\end{array}$ & Degree & 63,33 & 6,99 & 72,00 & 7,48 & 3,16 \\
\hline 5 & $\begin{array}{l}\text { The } \\
\text { accuracy of } \\
\text { passing the } \\
\text { ball directly } \\
\text { to the head }\end{array}$ & Degree & 18,67 & 3,39 & 20,50 & 6,11 & 3,07 \\
\hline 6 & $\begin{array}{l}\text { Shooting the } \\
\text { ball to a } \\
\text { specific part }\end{array}$ & Degree & 61,33 & 7,18 & 72,00 & 7,48 & 3,16 \\
\hline \hline
\end{tabular}

*The value of the table "T" at a significant level of $0.05=2,145$ 
Table (3) shows statistically significant differences at 0.05 level. Between the mean and postexperimental measurements of the experimental group in favor of post measure in all the individual skill level tests.

The calculated value $(\mathrm{t})$ was greater than the table value at 0.05 level. Table (4) shows statistically significant differences between the average of the premeasures And the exclusion of the control group in the level of individual skills under consideration for football players in favor of post measure.

The researcher returns these differences to the contents of the training program applied to the experimental group of compulsory technical exercises for some of the individual skills and integrated in the research, which have the specificity of the intended training, as it was the only variable that was added to the program of this group so the researcher can make any difference between The two groups to this variable, which indicates the importance of compulsory technical exercises in upgrading the skill level.

These results are consistent with the results of the study of Nody Shadin (2016) 12, Mustafa Abdullah (2015), 10 Talal Abdul Jawad (2011), 6 (6) 2003). These results indicated that there were statistically significant differences in the level of some of the individual basic skills in the experimental group.

Thus, the validity of the first hypothesis, which states that "the proposed training program has a positive impact on improving some of the individual skills of footballers in favor of the experimental group".

\section{Presentation and discussion of the results of the second hypothesis}


Table (5)

The significance of the differences between the pre and post measurements of the experimental group In the level of integrated skills under $\operatorname{study}(n=15)$

\begin{tabular}{|c|c|c|c|c|c|c|c|c|}
\hline \multirow[b]{2}{*}{ Serial } & \multirow{2}{*}{\multicolumn{2}{|c|}{ Variables }} & \multirow{3}{*}{$\begin{array}{c}\begin{array}{c}\text { Measure } \\
\text { unit }\end{array} \\
\mathrm{S} \\
\end{array}$} & \multicolumn{2}{|c|}{ Pre measure } & \multicolumn{2}{|c|}{ Post measure } & \multirow{3}{*}{$\begin{array}{c}\begin{array}{c}\text { Calculated } \\
\text { value (t) }\end{array} \\
* 6,17 \\
\end{array}$} \\
\hline & & & & SMA & $\begin{array}{l}\text { standard } \\
\text { deviation }\end{array}$ & SMA & $\begin{array}{l}\text { Standard } \\
\text { deviation }\end{array}$ & \\
\hline \multirow{3}{*}{1} & \multirow{3}{*}{$\begin{array}{r}\text { Control } \\
\text { then } \\
\text { pass }\end{array}$} & Chest & & 5,87 & 0,36 & 4,95 & 0,42 & \\
\hline & & Thigh & $S$ & 5,67 & 0,36 & 4,69 & 0,40 & $* 6,82$ \\
\hline & & Suppress & $S$ & 5,42 & 0,31 & 4,70 & 0,33 & $* 5,95$ \\
\hline \multirow{3}{*}{2} & \multirow{3}{*}{$\begin{array}{l}\text { Control } \\
\text { and then } \\
\text { shooting }\end{array}$} & Chest & $S$ & 6,02 & 0,37 & 5,20 & 0,31 & $* 6,22$ \\
\hline & & Thigh & $S$ & 5,42 & 0,73 & 4,39 & 0,50 & $* 6,12$ \\
\hline & & Suppress & $S$ & 5,63 & 0,69 & 4,06 & 0,63 & $* 6,31$ \\
\hline 3 & \multicolumn{2}{|c|}{$\begin{array}{l}\text { Control then dodge } \\
\text { then pass }\end{array}$} & S & 9,83 & 0,73 & 7,95 & 0,73 & $* 6,82$ \\
\hline \multirow{2}{*}{4} & \multirow{2}{*}{\multicolumn{2}{|c|}{$\begin{array}{l}\text { Control then dodge } \\
\text { and then shooting }\end{array}$}} & $\mathrm{S}$ & 9,22 & 0,47 & 8,06 & 0,50 & $* 6,29$ \\
\hline & & & Degree & 24,00 & 8,00 & 33,00 & 4,89 & $* 6,10$ \\
\hline 5 & \multicolumn{2}{|c|}{$\begin{array}{l}\text { Control then run the } \\
\text { ball then pass }\end{array}$} & S & 9,53 & 0,59 & 8,11 & 0,55 & $* 6,52$ \\
\hline \multirow{2}{*}{6} & \multirow{2}{*}{\multicolumn{2}{|c|}{$\begin{array}{l}\text { Control then run the } \\
\text { ball and then shooting }\end{array}$}} & $\mathrm{S}$ & 8,99 & 0,45 & 7,87 & 0,49 & $* 6,20$ \\
\hline & & & Degree & 32,67 & 5,73 & 46,67 & 5,96 & $* 6,33$ \\
\hline 7 & $\begin{array}{l}\text { Control } t \\
\text { then run a }\end{array}$ & $\begin{array}{l}\text { en dodge } \\
\text { ad pass }\end{array}$ & $S$ & 11,07 & 0,47 & 9,90 & 0,46 & $* 6,57$ \\
\hline \multirow{2}{*}{8} & \multirow{2}{*}{\multicolumn{2}{|c|}{$\begin{array}{l}\text { Control then dodge then } \\
\text { run and then shooting }\end{array}$}} & $\mathrm{S}$ & 11,29 & 0,42 & 10,16 & 0,53 & $* 6,28$ \\
\hline & & & Degree & 21,33 & 4,98 & 28,66 & 4,98 & $* 7,07$ \\
\hline
\end{tabular}

*Tab value at the level of $0.05=2.145$

\section{Table (6)}

Significance of differences between the pre and post measurements of the control group In the level of integrated skills under study $n=15$

\begin{tabular}{|c|c|c|c|c|c|c|c|c|}
\hline \multirow[b]{2}{*}{ Serial } & \multirow{2}{*}{\multicolumn{2}{|c|}{ Variables }} & \multirow{2}{*}{$\begin{array}{c}\text { Measure } \\
\text { unit }\end{array}$} & \multicolumn{2}{|c|}{ Pre measure } & \multicolumn{2}{|c|}{ Post measure } & \multirow{2}{*}{$\begin{array}{l}\text { Calculated } \\
\text { value }(t)\end{array}$} \\
\hline & & & & SMA & $\begin{array}{l}\text { standard } \\
\text { deviation }\end{array}$ & SMA & $\begin{array}{l}\text { standard } \\
\text { deviation }\end{array}$ & \\
\hline \multirow{3}{*}{1} & \multirow{3}{*}{$\begin{array}{l}\text { Control } \\
\text { then } \\
\text { pass }\end{array}$} & Chest & $S$ & 5,49 & 0,35 & 4,49 & 0,35 & $* 3,38$ \\
\hline & & Thigh & $S$ & 5,76 & 0,41 & 5,19 & 0,45 & $* 3,52$ \\
\hline & & Suppress & $\mathrm{S}$ & 5,51 & 0,28 & 5,14 & 0,28 & $* 3,38$ \\
\hline \multirow{3}{*}{2} & \multirow{3}{*}{$\begin{array}{l}\text { Control } \\
\text { and then } \\
\text { shooting }\end{array}$} & Chest & $\mathrm{S}$ & 6,13 & 0,41 & 5,65 & 0,40 & $* 3,08$ \\
\hline & & Thigh & $\mathrm{S}$ & 5,97 & 0,80 & 5,08 & 0,71 & $* 3,09$ \\
\hline & & Suppress & $\mathrm{S}$ & 5,87 & 0,79 & 4,93 & 0,79 & $* 3,13$ \\
\hline 3 & \multicolumn{2}{|c|}{$\begin{array}{l}\text { Control then dodge } \\
\text { then pass }\end{array}$} & S & 9,99 & 0,93 & 8,92 & 0,82 & $* 3,24$ \\
\hline
\end{tabular}


Follow Table (6)

Significance of differences between the pre and post measurements of the control group In the level of integrated skills under study $n=15$

\begin{tabular}{|c|c|c|c|c|c|c|c|}
\hline \multirow[b]{2}{*}{ Serial } & \multirow[b]{2}{*}{ Variables } & \multirow[b]{2}{*}{$\begin{array}{l}\text { Measure } \\
\text { unit }\end{array}$} & \multicolumn{2}{|c|}{ Pre measure } & \multicolumn{2}{|c|}{ Post measure } & \multirow[b]{2}{*}{$\begin{array}{l}\text { Calculated } \\
\text { value }(t)\end{array}$} \\
\hline & & & SMA & $\begin{array}{l}\text { standard } \\
\text { deviation }\end{array}$ & SMA & $\begin{array}{l}\text { standard } \\
\text { deviation }\end{array}$ & \\
\hline \multirow{2}{*}{4} & \multirow{2}{*}{$\begin{array}{l}\text { Control then dodge } \\
\text { and then shooting }\end{array}$} & $\mathrm{S}$ & 9,33 & 0,41 & 8,71 & 0,41 & $* 3,97$ \\
\hline & & Degree & 26,67 & 9,43 & 29,33 & 7,18 & $* 63,94$ \\
\hline 5 & $\begin{array}{l}\text { Control then run the } \\
\text { ball then pass }\end{array}$ & $\mathrm{S}$ & 9,64 & 0,68 & 8,86 & 0,48 & $* 3,48$ \\
\hline \multirow[b]{2}{*}{6} & \multirow{2}{*}{$\begin{array}{l}\text { Control then run the } \\
\text { ball and then } \\
\text { shooting }\end{array}$} & $\mathrm{S}$ & 9,14 & 0,43 & 8,53 & 0,43 & $* 3,74$ \\
\hline & & Degree & 31,33 & 6,18 & 39,33 & 6,79 & $* 3,25$ \\
\hline 7 & $\begin{array}{l}\text { Control then dodge } \\
\text { then run and pass }\end{array}$ & $\mathrm{S}$ & 10,79 & 0,44 & 10,45 & 0,44 & $* 3,14$ \\
\hline \multirow[b]{2}{*}{8} & \multirow{2}{*}{$\begin{array}{l}\text { Control then dodge } \\
\text { then run and then } \\
\text { shooting }\end{array}$} & $\mathrm{S}$ & 11,37 & 0,43 & 10,83 & 0,45 & $* 3,28$ \\
\hline & & Degree & 22,67 & 4,42 & 25,33 & 5,05 & $* 63,16$ \\
\hline
\end{tabular}

*Tab value at the level of $0.05=2.145$

Table (5) shows that there are statistically significant differences at the level of 0.05 between the mean and the post and for the postexperimental benefit of the experimental group in all the combined skill level tests. Table (6) reveals statistically significant differences between the mean and the premeasures of the control group at the level of skills combined Search and for the afterlife.

The researcher returns these differences between the pre and post measurements and the post-experimental benefit of the experimental group in the tests of individual and integrated skills under the research to the proposed training program applied to the experimental group, which contains consensual exercises similar to the nature of performance in football and which have the specificity intended in the training, Which indicates the importance of compulsory technical training to develop the skill level.

These results are consistent with the results of both Pflor Steyen (2016), Ahmed AlHenidi (2013), Ahmed Ibrahim (2011), Mostafa Zaki (2008), 9 Mohamed Abdel-Sattar (2004) (7), all of which indicated statistically significant differences between the pre and post indices in some integrated skills and the skill 
level of performance and for the benefit of the postmeasurement in the experimental group.

Thus, the second hypothesis, which states that there are statistically significant differences between the mean (pre- post) of the experimental group and the level of some of the skills combined for the benefit of post measure.

-Presentation and discussion of the results of the third hypothesis:

\section{Table (7)}

Indication of differences between the two dimensions of the experimental groups the control at the level of individual skills in question is $n=1 \mathrm{n}=15$

\begin{tabular}{|c|c|c|c|c|c|c|c|}
\hline \multirow[b]{2}{*}{ Serial } & \multirow[b]{2}{*}{ Variables } & \multirow{2}{*}{$\begin{array}{l}\text { Measure } \\
\text { unit }\end{array}$} & \multicolumn{2}{|c|}{ Experimental group } & \multicolumn{2}{|c|}{ Control group } & \multirow{2}{*}{$\begin{array}{c}\text { Calculated } \\
\text { value }(t)\end{array}$} \\
\hline & & & SMA & $\begin{array}{l}\text { standard } \\
\text { deviation }\end{array}$ & SMA & $\begin{array}{l}\text { standard } \\
\text { deviation }\end{array}$ & \\
\hline 1 & Control the ball & Degree & 72,00 & 7,48 & 62,00 & 8,33 & $* 3,46$ \\
\hline 2 & Various passing & Degree & 69,33 & 4,42 & 68,00 & 4,00 & $0,87 *$ \\
\hline 3 & $\begin{array}{l}\text { Accuracy } \\
\text { Seam pitch }\end{array}$ & Degree & 74,00 & 8,00 & 72,00 & 7,48 & $0,71 *$ \\
\hline 4 & $\begin{array}{l}\text { The accuracy } \\
\text { of passing the } \\
\text { ball directly by } \\
\text { the head }\end{array}$ & Degree & 24,83 & 2,49 & 20,50 & 6,11 & $3,13^{*}$ \\
\hline 5 & $\begin{array}{l}\text { Shooting the } \\
\text { ball to a } \\
\text { specific part }\end{array}$ & Degree & 82,00 & 9,09 & 72,00 & 7,48 & $3,29 *$ \\
\hline
\end{tabular}

$* \mathrm{~T}$ value of the table at a significant level of $0.05=2,048$

Table (8)

Indication of differences between the two dimensions of the experimental groups the control at the level of integrated skills under consideration is $\mathrm{n}=1 \mathrm{n}=15$

\begin{tabular}{|c|c|c|c|c|c|c|c|c|}
\hline \multirow[b]{2}{*}{ Serial } & \multirow{2}{*}{\multicolumn{2}{|c|}{ Variables }} & \multirow{2}{*}{$\begin{array}{c}\text { Measure } \\
\text { unit }\end{array}$} & \multicolumn{2}{|c|}{ Experimental group } & \multicolumn{2}{|c|}{ Control group } & \multirow{2}{*}{$\begin{array}{c}\text { Calculated } \\
\text { value (t) }\end{array}$} \\
\hline & & & & SMA & standard & SMA & standard & \\
\hline \multirow{3}{*}{1} & \multirow{3}{*}{$\begin{array}{l}\text { Control } \\
\text { then } \\
\text { pass }\end{array}$} & Chest & $\mathrm{S}$ & 5,87 & 0,36 & 4,49 & 0,35 & $* 3,84$ \\
\hline & & Thigh & $\mathrm{S}$ & 5,67 & 0,36 & 5,19 & 0,45 & $* 3,15$ \\
\hline & & Suppress & $\mathrm{S}$ & 5,42 & 0,31 & 5,14 & 0,28 & $* 3,92$ \\
\hline \multirow[b]{2}{*}{2} & \multirow{2}{*}{$\begin{array}{l}\text { Control } \\
\text { and then } \\
\text { shooting }\end{array}$} & Chest & S & 6,02 & 0,37 & 5,65 & 0,40 & $* 3,40$ \\
\hline & & Thigh & S & 5,42 & 0,73 & 5,08 & 0,71 & $* 3,05$ \\
\hline
\end{tabular}


Follow Table (8)

Indication of differences between the two dimensions of the experimental groups the control at the level of integrated skills under consideration is $n=1 \mathrm{n}=15$

\begin{tabular}{|c|c|c|c|c|c|c|c|}
\hline \multirow[b]{2}{*}{ Serial } & \multirow{2}{*}{ Variables } & \multirow{2}{*}{$\begin{array}{l}\text { Measure } \\
\text { unit }\end{array}$} & \multicolumn{2}{|c|}{ Experimental group } & \multicolumn{2}{|c|}{ Control group } & \multirow{2}{*}{$\begin{array}{l}\text { Calculated } \\
\text { value }(t)\end{array}$} \\
\hline & & & SMA & $\begin{array}{c}\text { standard } \\
\text { deviation }\end{array}$ & SMA & $\begin{array}{c}\text { standard } \\
\text { deviation }\end{array}$ & \\
\hline & \begin{tabular}{l|l|} 
& Suppress \\
\end{tabular} & $S$ & 5,63 & 0,69 & 4,93 & 0,79 & $* 3,32$ \\
\hline 3 & $\begin{array}{l}\text { Control then dodge } \\
\text { then pass }\end{array}$ & $S$ & 9,83 & 0,73 & 8,92 & 0,82 & $* 3,45$ \\
\hline \multirow{2}{*}{4} & \multirow{2}{*}{$\begin{array}{l}\text { Control then dodge } \\
\text { and then shooting }\end{array}$} & $\mathrm{S}$ & 9,22 & 0,47 & 8,71 & 0,41 & $* 3,90$ \\
\hline & & Degree & 24,00 & 8,00 & 29,33 & 7,18 & $* 3,87$ \\
\hline 5 & $\begin{array}{l}\text { Control then run the } \\
\text { ball then pass }\end{array}$ & $S$ & 9,53 & 0,59 & 8,86 & 0,48 & *3,94 \\
\hline \multirow[b]{2}{*}{6} & \multirow{2}{*}{$\begin{array}{l}\text { Control then run the } \\
\text { ball and then } \\
\text { shooting }\end{array}$} & $S$ & 8,99 & 0,45 & 8,53 & 0,43 & $* 3,86$ \\
\hline & & Degree & 32,67 & 5,73 & 39,33 & 6,79 & $* 3,14$ \\
\hline 7 & $\begin{array}{l}\text { Control then dodge } \\
\text { then run and pass }\end{array}$ & $S$ & 11,07 & 0,47 & 10,45 & 0,44 & $* 3,29$ \\
\hline \multirow[b]{2}{*}{8} & \multirow{2}{*}{$\begin{array}{l}\text { Control then dodge } \\
\text { then run and then } \\
\text { shooting }\end{array}$} & $S$ & 11,29 & 0,42 & 10,83 & 0,45 & $* 3,67$ \\
\hline & & Degree & 21,33 & 4,98 & 25,33 & 5,05 & $* 3,46$ \\
\hline
\end{tabular}

$*$ Tab value at the level of $0.05=2.145$

Table (8) shows values were smaller than the statistically significant differences between the mean of the two dimensions of the experimental and control groups in favor of the experimental group in the individual skills tests, where all calculated values were greater than the table values at 0.05 level, while there are no significant differences between The two dimensional measures of the experimental group and the control group in the various scroll tests, the accuracy of the pitch, where the calculated tabular values at the 0.05 level. The researcher points out that there is no indication between the mean of the two dimensional measurements of both experimental and control groups for the various scrolling test, the accuracy of the contact pitch to the similarity of the content of the compulsory technical exercises and the content of the exercises given to the control group.

As shown in Table (8), there are statistically significant differences between the mean 
of the two dimensions of the two experimental groups in favor of the experimental group in the combined skill level tests, where the calculated $\mathrm{T}$ values were greater than the tabular value at a significant level of 0.05 .

The researcher attributes the differences in the two dimensions between the experimental and control groups in the individual and integrated skills tests under consideration for the experimental group to the positive effect of the proposed program which included compulsory technical training to improve the individual and integrated skills. In constructing the necessary technical training, where the dynamic construction and the correlation of these exercises with the nature of the skilled performance under consideration, and the researcher also observed that the training used to develop more than the skill of mobility at the same time, and this was not available to the group's early Plan.

Gamal Alaeddin and Nahed Al-Sabbagh (1991) indicate that the composite skill performance is either consecutive, synchronous or tricky. The composite skill performance is consecutive in which the skill performances are integrated in a chronological order. Concurrently, the technical performances are synchronized in such a manner that it is not possible to clarify the sequence between them, The trick is a project in the performance of the preliminary stage offset by the reaction of the opponent and near the end of the preliminary stage the player makes a sudden cut and moves the course of the movement to a major stage of the performance of a new skill without a preliminary stage of his own (111: 4)

This is consistent with the findings of Nick Harris (2013), Ahmed Haidar (2012), Talal Abdul-Jawad (2011), and Khalid Kamal (2003). That the development of individual and integrated skills leads to the raising and progress of the level of technical performance.

Thus, the validity of the third hypothesis, which states that there are statistically significant differences between the pre and the parametric 
measurement in the skill performance variables of the measurement of the experimental group and the experimental group.

Presentation and control group and for the benefit of the post-

\section{Table (9)}

discussion of the results of the fourth hypothesis:

The percentage of improvement between the pre and post measurements of the experimental and control groups In the level of individual skills and level of integrated skills under consideration

\begin{tabular}{|c|c|c|c|c|c|c|c|c|}
\hline & \multirow{2}{*}{\multicolumn{2}{|c|}{ Variables }} & \multicolumn{3}{|c|}{ Experimental group } & \multicolumn{3}{|c|}{ Control group } \\
\hline & & & $\begin{array}{c}\text { Pre } \\
\text { measure }\end{array}$ & $\begin{array}{c}\text { Post } \\
\text { measure }\end{array}$ & $\begin{array}{l}\text { Improved } \\
\text { rate } \\
\end{array}$ & $\begin{array}{c}\text { Pre } \\
\text { measure }\end{array}$ & $\begin{array}{c}\text { Post } \\
\text { measure }\end{array}$ & $\begin{array}{c}\text { Improved } \\
\text { rate }\end{array}$ \\
\hline \multirow{5}{*}{ 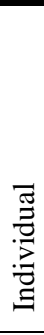 } & \multicolumn{2}{|c|}{ Control the ball } & or, TV & $V Y, \cdots$ & $r 7, v$. & $0 \leqslant, 7 V$ & $\pi, \cdots$ & $1 T, \leqslant 1$ \\
\hline & \multicolumn{2}{|c|}{ Various passing } & سו, (וד & 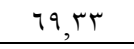 & $1 T, \varepsilon$ & $T Y, T V$ & $71, \cdots$ & $\wedge, 0$ \\
\hline & \multicolumn{2}{|c|}{ Accuracy Seam pitch } & $T r, \cdots$ & $v \varepsilon, \cdots$ & 19,10 & מח, יד & $V Y, \cdots$ & 15,79 \\
\hline & \multicolumn{2}{|c|}{$\begin{array}{l}\text { The accuracy of passing } \\
\text { the ball directly by the } \\
\text { head }\end{array}$} & $11, \cdots$ & $r \varepsilon, \wedge r$ & $r v, q \varepsilon$ & $11,7 \mathrm{~V}$ & $r \cdot, 0$. & $9, \wedge$. \\
\hline & \multicolumn{2}{|c|}{$\begin{array}{l}\text { Shooting the ball to } \\
\text { a specific part }\end{array}$} & אי, & $\Lambda r, \cdots$ & $r q, \leqslant \wedge$ & חיז, יד & $V Y, \cdots$ & IV,rq \\
\hline & \multirow{3}{*}{$\begin{array}{l}\text { Control } \\
\text { then } \\
\text { pass }\end{array}$} & Chest & $0, \wedge \mathrm{V}$ & $\varepsilon, 90$ & $10,7 \mathrm{~V}$ & $0, \leqslant 9$ & $\varepsilon, \leqslant 9$ & $\mathrm{~V}, 0 \mathrm{~V}$ \\
\hline & & Thigh & $0,7 V$ & $\varepsilon, 79$ & $I V, Y \Lambda$ & $0, V 7$ & 0,19 & $9, \wedge 9$ \\
\hline & & Suppress & $0, \leqslant Y$ & $\varepsilon, V$ & $M, Y A$ & 0,01 & $0,1 \leq$ & $7, \times 1$ \\
\hline & \multirow{3}{*}{$\begin{array}{l}\text { Control } \\
\text { and then } \\
\text { shooting }\end{array}$} & Chest & $7, \cdot r$ & $0, Y$. & Ir, & 7,14 & 0,70 & v, س \\
\hline & & Thigh & $0, \leqslant Y$ & $\varepsilon, \mu$ & $r \varepsilon, \wedge r$ & $0,9 V$ & 0,1 & $1 \leq, 91$ \\
\hline & & Suppress & טד, 0, & $\varepsilon, \cdot 7$ & $r V, \wedge \Lambda$ & $0, \wedge V$ & $\varepsilon, 94$ & $17, \cdot 1$ \\
\hline & \multicolumn{2}{|c|}{$\begin{array}{l}\text { Control then dodge } \\
\text { then pass }\end{array}$} & $q, \wedge r$ & $v, 90$ & 19,15 & 9,99 & $\wedge, 9 r$ & $1 \cdot, v_{1}$ \\
\hline & \multirow{2}{*}{\multicolumn{2}{|c|}{$\begin{array}{l}\text { Control then dodge } \\
\text { and then shooting }\end{array}$}} & $q, r\}$ & $\Lambda, \cdot 7$ & $1 T, 01$ & سب, & $\wedge, V_{1}$ & $7,7 \leq$ \\
\hline & & & $r \varepsilon, \cdots$ & r,... & $r v, 0$. & $Y T, T V$ & rq,r & $9,9 \vee$ \\
\hline & \multicolumn{2}{|c|}{$\begin{array}{l}\text { Control then run the } \\
\text { ball then pass }\end{array}$} & 9,0 r & $\wedge, 11$ & $1 \leq, 9$. & $9,7 \leq$ & $\wedge, \wedge\rceil$ & $\wedge, \cdot 9$ \\
\hline & \multirow{2}{*}{\multicolumn{2}{|c|}{$\begin{array}{l}\text { Control then run the } \\
\text { ball and then shooting }\end{array}$}} & 1,99 & $\vee, \wedge V$ & $M, \leqslant T$ & $9,1 \leq$ & 1,or & $7,7 V$ \\
\hline & & & rT,TV & $\varepsilon 7,7 V$ & $\varepsilon r, \wedge 0$ & rr, וr & rq,r & ro,or \\
\hline \multirow{3}{*}{ 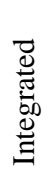 } & \multicolumn{2}{|c|}{$\begin{array}{l}\text { Control then dodge } \\
\text { then run and pass }\end{array}$} & $11, \cdot v$ & $9,9$. & $1 ., 0 \mathrm{~V}$ & $1 \cdot, \times 9$ & $1 \cdot, \leqslant 0$ & $\varepsilon, \varepsilon V$ \\
\hline & \multirow{2}{*}{\multicolumn{2}{|c|}{$\begin{array}{l}\text { Control then dodge } \\
\text { then run and then } \\
\text { shooting }\end{array}$}} & 11,19 & $1 \cdot, 17$ & $1 \cdot, \cdot 1$ & $11, r v$ & 1., & $\varepsilon, V_{0}$ \\
\hline & & & rr, & $r \wedge, 7 T$ & דוr, & YY,TV & ro,r & $11, \mathrm{~V}$ \\
\hline
\end{tabular}


The results of Table (9) showed the improvement of the post-pre measurement of the experimental and control groups in the level of individual and integrated skills and for the benefit of the experimental group. The differences in the rates of improvement of individual skills in the experimental group ranged between (37.94). In the control group, ranged from (17.39) for the correction of the ball to a certain segment and $(8,50)$ for the different passing test. In the combined skills of the experimental group, the improvement rates ranged between $(42,85)$ Control and then run the ball and then the correction and $(10,01)$ to test the control then $m$ And then in the control group ranged between (25.53) to test the control and then run the ball and then the correction and $(4,47)$ to test the control and then dodge and then run the ball and then pass.

The researcher attributed this improvement in the level of performance of the individual and integrated skills of the experimental group compared to the control group to the content of the proposed program of the proposed mandatory technical exercises. This is in line with Ahmed AlHenidi's (2013) (1): There is a correlation between the skills and kinetic skills Represent a fundamental basis for the acquisition of kinetic skills and in such a way as to show the extent to which the level of each other depends on the other.

As Ahmed Ibrahim (2011) indicates (2) that the composite motor performance in general is a form of building consisting of several interconnected kinetic performances that affect each other. The composite skill performance consists of several single performances (receiving or passing) or multiple repetitive performances (Running the ball) or several performances include the two together (receipt and then running and then scrolling) and this requires the sequence of technical performances and the integration of the final stage with the preparatory stage of the second performance to form a stage integrated with a special interface.

This is consistent with the results of the study of Nody 
Shadin (2016), 12, Stephen Ploor Steyen (2016), 13 Mustafa Abdullah (2015), Ahmed Al-Henidi (2013), Talal Abdul-Jawad (6), Ahmed Ibrahim (2011) (2), Mostafa Zaki (2008) (9)

Based on the above, the fourth hypothesis is achieved in the research, which states that "there are differences in the rate of improvement between the experimental and control groups at the level of some individual skills and integrated for the benefit of the experimental group".

\section{-Conclusions}

and

\section{Recommendations:}

In light of the research objectives, hypotheses and results, the researcher concluded the following:

-The proposed training program has a positive effect on the development of some of the individual skills in the field of "ball control, ball head accuracy, variable scroll accuracy, shooting the ball, accuracy of pitch" at the 15year-old footballer.

-There were no statistically significant differences between the results of the two dimensions of the experimental and control groups in order to approximate the training content of the two groups, which led to convergence of performance levels.

-The proposed training program has had a positive impact on improving some of the skills integrated in the football player.

-Differences in the rates of improvement of the grades and times of individual and combined skills tests between the experimental and control groups of the youth of the sample.

- Recommendations:

In light of the results of the research and its conclusions, the researcher recommends the following:

-The use of compulsory technical exercises to develop the individual skills and integrated with the youth football in all stages of the year.

-The need for the trainers to pay attention to the quality of the individual and integrated skills and put them in training graded difficulty in terms of composition, making them more interesting and similar to what happens in matches.

-Use the appropriate training methods and techniques to 
upgrade the individual skills and integrated into the special football for young people.

-Guided by the scientific foundations in the construction and design of training programs to improve the skills of young people in football.

-Conducting similar research at different age stages in order to achieve optimal and integrated performance to create a broad base of distinguished players.

\section{References:}

\section{1-Ahmed Mohamed Hamed}

Haidar: The Effect of Complex Performance Performances on the Effectiveness of Attacking Performance of Football Creators, PhD Thesis, Faculty of Physical Education, Benin, Banha University, 2012.

\section{2-Ahmed Mohamed Ibrahim} Al-Henaidi: a training program for the abilities of cognitive sense - motor and its impact on the level of performance skill in football, $\mathrm{PhD}$ thesis, Faculty of Physical Education, Tanta University, $2013 \mathrm{~m}$.

\section{3-Ahmed Mohamed Ibrahim Mustafa: Evaluation of the effectiveness of some complex motor performances -}

integrated to the various play centers in the World Youth Championship for football 2009, Master, Faculty of Physical Education Boys, Zagazig University, 2011.

\section{4-Gamal Mohamed Alaa El} Din: A Biomechanical Entrance to Evaluate the Level of Mastery of Skill Performance in the Field of Sports, Faculty of Physical Education for Boys, Alexandria, Helwan University, 1991.

\section{5-Khalid Mohammed Kamal:} the development of some aspects of the performance of the skill and its relationship to some of the sentences of the junior football players under 19 years during the preparation period, Master, Faculty of Physical Education Boys, Zagazig University, 2003.

\section{6- Mohamed Abdel-Sattar} Mahmoud Abdel-Qader: The Effect of Development of Composite Motor Performance on Some Physical Fitness Components of Youngsters in Football, Master Thesis, Faculty of Physical Education for Boys, Zagazig University, 2005.

7-Mustafa Abdalla AbdelMaksoud: Effect of Interactive 
Training on the Development of Some Physical and Vocational Skills for Football Buds, Master Thesis, Faculty of Physical Education for Boys, Banha University, 2015.

\section{8-Mustafa Abdel Hamid}

Zaki: Development of some of the composite motor performances - combined offensive to the football youth, a $\mathrm{PhD}$ thesis, Faculty of Physical Education for Boys, Zagazig University, 1998.

\section{9-Mustafa}

Abdel-Hamid

Zaki: A Comparative Study of the Performance of Passing of Some Complex-Compound Performance Performances for High Level Attackers in Football, Scientific Journal No. 87, Vol. 2, Faculty of Physical Education for Boys, Zagazig University, 2008.

10- Nick Harris : Forign players at records levels across
Europan fottball, 3rd., ed., Macmillan Publishing Go . Inc., New Yourk, 2013.

11- Nody Shadin: Application of measurement to Health and Physical Education, 3 rd.,ed., Prentice Hall, Inc., Chicago, 2016.

12- Ploor Steyen: Variation in duration of training period on the performance variables of young soccer players. , Fn., Sports, New York, 2016.

13- Robert $M$ Malina \& others :Motor control and learning human kinetics, Publishers, Champaign, Illinois, 2007.

\section{4- Talal Al-Sayed Abdel-} Jawad: Effectiveness of training program on the performance of the offensive movement of soccer players, $\mathrm{PhD}$ thesis, Faculty of Physical Education Benin, Zagazig University, 2011. 